\title{
PENERAPAN OPEN LEARNING COURSE BAGI LEMBAGA PENDIDIKAN ISLAM (Analisis Persepsi Pengelola Pesantren di Kabupaten Kudus-Jawa Tengah)
}

\author{
Nuskhan Abid \\ Sekolah Tinggi Agama Islam Negeri (STAIN) Kudus, Jawa Tengah \\ Jl. Conge Ngembalrejo, Po Box 51 Kudus, Jawa Tengah 59322 \\ E-mail: nuskhan@stainkudus.ac.id
}

\begin{abstract}
Open Learning Course Application For Islamic Education Institutions (Perception Analysis of Pesantren Management in Kabupaten Kudus-Central Java). Information and Communication Technology (TIK) is speeding up. It also affects the development of the distribution of pure religious sciences. Islamic educational institutions such as pesantren are the spearheads in the distribution of religious knowledge that still survive with traditional learning models. This article aims to find out the perception of managers of Islamic educational institutions, especially pesantren about open learning based online. The method used is qualitative with observation and distribution questionnaire to get data. The result is that the majority of pesantren managers in Kabupaten Kudus, Central Java Indonesia still retains traditional learning models rather than trying to develop open learning courses because of the lack of reference and insight about open learning course. Socialization about open learning and the importance of the distribution of pure religious knowledge is needed for the development of open learning in the future.
\end{abstract}

Keywords: Islamic educational institution; pesantren; Open Learning Course; distribution of religious knowledge.

\begin{abstract}
Abstrak: Penerapan Open Learning Course Bagi Lembaga Pendidikan Islam (Analisis Persepsi Pengelola Pesantren Di Kabupaten Kudus-Jawa Tengah). Teknologi Informasi dan Komunikasi (TIK) melaju semakin kencang. Hal ini juga berdampak pada perkembangan persebaran ilmu-ilmu agama yang murni. Lembaga pendidikan Islam seperti pesantren merupakan ujung tombak dalam persebaran ilmu agama masih bertahan dengan model pembelajaran tradisional. Artikel ini bertujuan untuk mengetahui persepsi pengelola lembaga pendidikan Islam khususnya pesantren tentang pembelajaran terbuka (open learning) berbasis daring. Metode yang digunakan adalah kualitatif dengan observasi dan sebaran kuesioner untuk mendapatkan data. Hasilnya adalah mayoritas para pengelola pesantren di Kabupaten Kudus, Jawa Tengah Indonesia masih tetap mempertahankan model pembelajaran tradisional daripada mencoba mengembangkan open learning course karena minimnya referensi dan wawasan tentang pembelajaran terbuka. Sosialisasi tentang open learning dan pentingnya persebaran ilmu agama yang murni sangat dibutuhkan untuk pengembangan pembelajaran terbuka di masa depan.
\end{abstract}

Kata kunci: lembaga pendidikan Islam; pesantren; Open Learning Course; persebaran ilmu agama.

\section{Pendahuluan}

Open Learning Course (OLC) adalah sebuah konsep pembelajaran yang memberikan kemerdekaan kepada siapapun untuk belajar tanpa terbatas pada ruang, waktu, ataupun status dan golongan seseorang. Sejatinya OLC merupakan salah satu inovasi dalam dunia belajar dan pembelajaran karena hadirnya teknologi. Teknologi Informasi dan Komunikasi (TIK) saat ini telah menjadi kebutuhan utama bagi setiap orang. Perkembangan yang begitu cepat membuat kita bergantung dengan produk-produk teknologi karena kemudahan-kemudahan yang ditawarkan. Hal memaksa dunia pendidikan untuk dapat menyesuaikan dengan perkembangan Teknologi Informasi dan Komunikasi (TIK). Rusman, Kurniawan, \& Riyana' menyatakan bahwa tuntutan global menuntut dunia pendidikan untuk selalu senantiasa menyesuaikan perkembangan teknologi terhadap usaha peningkatan mutu pendidikan, terutama penyesuaian penggunaannya bagi dunia pendidikan dalam proses pembelajaran. Evolusi dan integrasi TIK dalam dunia pendidikan telah membawa perubahan yang spesifik dalam

${ }^{1}$ Rusman, Deni Kurniawan, dan Cepi Riyana, Pembelajaran Berbasis Teknologi Informasi dan Komunikasi Mengembangkan Profesionalitas Guru, PT. Raja Grafindo Persada, (Depok: PT Raja Grafindo Persada, 2012), h. 1. 
program pembelajaran baik di level persiapan pendidikan (pre-service education) maupun dalam tahapan in service education ${ }^{2}$.

Ilmu agama yang orisinil akan tergerus dan terganti oleh ajaran-ajaran Islam yang radikal, liberal ataupun yang tidak sesuai dengan kaidah sebenarnya. Karena kebebasan mengakses informasi melalui media dalam jaringan memudahkan setiap orang untuk belajar dari situssitus Islam di luar negeri. Lahirnya Islam garis keras yang gemar melakukan bom bunuh diri, ujaran-ujaran kebencian terhadap pihak-pihak tertentu, ataupun standar ganda yang negatif tentang Islam disinyalir karena adanya ajaranajaran terstruktur yang disebarkan melalui jaringan internet. Lembaga pendidikan Islam seharusnya mampu untuk memberikan pencerahan dan klarifikasi terkait preseden buruk yang dimunculkan oleh media tentang Islam dengan cara menyebarkan kebaikan melalui media yang sama pula. Menyebarluaskan ilmu-ilmu Islam yang mengajarkan tentang kedamaian, kerukunan dan toleransi tidak cukup hanya dari dakwah mulut ke mulut ataupun ruang kelas saja. Elemen-elemen pendukung pendidikan Islam seperti guru, banyak yang tidak memanfaatkan internet, teknologi dan media dalam proses pembelajaran di kelas. Selain itu materi-materi pembelajaran tentang ilmu-ilmu keislaman mereka hanya tersimpan rapi dalam folder-folder laptop, dan rak-rak meja kantor. Faktor lemahnya penguasaan terhadap produk TIK menjadikan kendala tersendiri bagi setiap pengajar.

Keterbatasan sarana-prasarana dan media menjadikan guru tidak mempunyai pilihan untuk melakukan proses pembelajaran selain di dalam kelas. ${ }^{3}$ Selama ini penggunaan TIK belum berjalan secara optimal seperti yang ada dalam penelitian yang dilakukan oleh Chaidar Husain yang menyebutkan bahwa paradigma penggunaan TIK dalam dunia pendidikan hanya

2 Oana Chisalita dan Carmen Cretu, "Opinions and Attitudes of Students Teachers' Toward ICT Use in Education," in The 8 th International Scientific Conference elearning and software for Education, 2012, 548.

${ }^{3}$ Ismail Suardi Wekke dan Sanusi Hamid, "Technology on Language Teaching and Learning: A Research on Indonesian Pesantren," Procedia - Social and Behavioral Sciences 83 (2013): 585. sebatas pada penggunaan media presentasi saja ${ }^{4}$. Sejatinya potensi untuk mengembangkan lembaga pendidikan Islam berbasis teknologi dan pembelajaran terbuka (open learning) sangatlah besar. Dengan modal bahwa mayoritas penduduk Indonesia adalah muslim, seharusnya hal ini membawa dampak yang positif dalam usaha memajukan pendidikan di lembaga pendidikan Islam serta menyebarluaskan ajaran Islam yang otentik melalui penggunaan teknologi di dalamnya. Hal ini dilakukan untuk menolak ajaran-ajaran Islam yang tidak sesuai dengan kaidah.

Lembaga pendidikan Islam ${ }^{5}$ di Kabupaten Kudus propinsi Jawa Tengah Indonesia, terus konsisten untuk meneruskan tradisi dalam proses belajar dan pembelajaran. Semuanya masih dilakukan secara klasikal dan dilakukan pada waktu tertentu saja di dalam lingkungan sekolah ataupun pesantren. Hal ini akan membuat interaksi dengan pendidik dan santri menjadi terbatas, hanya kalangan tertentu (santri yang mondok) saja yang dapat mengikuti proses belajar pembelajaran di pesantren ataupun madrasah diniyah, sehingga penyebaran ilmuilmu keislaman menjadi sangat-sangat terbatas. Masyarakat muslim yang berada di luar lembaga pendidikan Islam tidak dapat berpartisipasi secara langsung untuk mempelajari ilmu-ilmu Islam di dalamnya. Mayoritas penduduk Indonesia adalah muslim, namun tidak semuanya memilih lembaga pendidikan Islam baik yang formal maupun yang non formal sebagai tempat untuk belajar ilmu keagamaan. Hal ini berdampak pada penyebaran ilmu Islam yang otentik dan sesuai dengan kearifan lokal. Persebaran ilmu agama secara luas melalui bantuan teknologi seirama dengan tujuan utama untuk mensyiarkan agama kepada siapapun juga.

Wekke dan Hamid ${ }^{6}$ menyatakan bahwa penggunaan teknologi di pesantren memegang

${ }^{4}$ Chaidar Husain, "Pemanfaatan Teknologi Informasi dan Komunikasi dalam Pembelajaran di SMA Muhammadiyah Tarakan," Jurnal Kebijakan dan Pengembangan Pendidikan 2, no. 2 (2014), h. 191.

5 Yang dimaksud dengan lembaga pendidikan Islam disini adalah; UIN, IAIN, STAIN, Pesantren, Madrasah Diniyah, Madrasah Aliyah, Madrasah Tsanawiyah, Madrasah Ibtidaiyah.

${ }^{6}$ Wekke dan Hamid, "Technology on Language Teaching and Learning: A Research on Indonesian Pesantren," 585. 
peranan penting dalam proses peningkatan pemahaman santri. Selain itu Rosyid ${ }^{7}$ dalam penelitiannya fokus kepada sejarah bahwa pesantren dan diniyah merupakan penyedia tatanan ilmu Islam yang paling mendasar. Dari beberapa penelitian di atas, diharapkan dapat dibangun sebuah model pembelajaran berbasis teknologi untuk memfasilitasi orang di luar pesantren atau madrasah diniyah untuk dapat belajar ilmu Islam yang murni dan otentik melalui media dalam jaringan seperti website, media sosial ataupun video multimedia interaktif. Metode yang digunakan dalam penelitian ini adalah metode kualitatif. Data didapatkan dari observasi dan wawancara.

Artikel ini bertujuan untuk mengetahui respon lembaga pendidikan Islam di Kudus (terutama pesantren) tentang penggunaan teknologi informasi dan komunikasi (internet dan media sosial) dalam proses pembelajaran. Bagaimana persepsi para pengelola dalam hal penggunaan TIK di lingkungan pesantren, madrasah diniyah, aliyah, tsanawiyah, ataupun lembaga pendidikan Islam lainnya untuk menyebarluaskan materi-materi pembelajaran mereka melalui bantuan teknologi. Dengan demikian, materi yang ada di pesantren dapat dikaji oleh setiap muslim dimanapun mereka berada. Diharapkan dari penelitian ini seluruh komponen lembaga pendidikan Islam dapat menerapkan pembelajaran terbuka berbantuan internet untuk kemajuan lembaga pendidikan Islam dan persebaran ilmu-ilmu Islam yang otentik di masa yang akan datang. Sehingga proses penyebaran ilmu menggunakan media internet memudahkan orang lain untuk mengakses dan belajar materi-materi di pondok pesantren atau lembaga pendidikan Islam lainnya.

\section{Dari Budaya Klasikal Bertransformasi Ke Digital}

Teknologi informasi dan komunikasi (TIK) sangat dekat dengan komputer, internet dan segala sesuatu yang berhubungan dengan alat-alat yang berbasis elektronik. Teknologi informasi dan komunikasi adalah kajian untuk mengefektifkan

7 Moh Rosyid, “Diniyah Muawanatul Muslimin Sejak Era Pra-Kolonial Dengan Diberlakukannya Perda Kabupaten Kudus Tentang Madin Takmiliyah," Elementary 3, no. 1, (2015), h. 59. proses komunikasi dengan bantuan teknologi ${ }^{8}$. Artinya teknologi dapat memberikan kemudahan untuk berkomunikasi dan berinteraksi dengan semua orang. Ketika hal ini diterapkan dalam proses pembelajaran akan membawa kemudahan dalam hal berkomunikasi atau lebih tepatnya untuk menyampaikan materi pembelajaran. Pembelajaran berbasis TIK menuntut adanya perubahan paradigma dan konsep dalam proses belajar dan mengajar. Saat ini konsepsi bahwa guru merupakan sumber utama pengetahuan harus dihilangkan. Guru lembaga pendidikan Islam harus menyesuaikan dengan tuntutan kemajuan zaman. Guru seharusnya mampu membangkitkan potensi dan kemampuan siswa. Pengintegrasian pengetahuan, pengalaman, dan kemahiran seorang guru dalam kondisi pembelajaran yang aktif dan menyenangkan adalah hal yang wajib untuk dilakukan, karena guru adalah seorang mediator dan fasilitator bagi siswa9.

Penggunaan TIK dalam proses pembelajaran sejatinya bukan hal yang baru dalam dunia pendidikan. Proses pembelajaran berbasis TIK menuntut siswa untuk lebih aktif dan menghilangkan kesan bahwa guru hanyalah seseorang penyampai pesan saja ${ }^{10}$. Guru sebaiknya tidak memonopoli dan menguasai arena kelas tanpa memberikan kesempatan kepada siswa untuk berkembang. Metode ceramah yang sering digunakan oleh seorang guru dalam menyampaikan materi seringkali meniadakan posisi siswa di dalam kelas. Guru terlalu mendominasi dan tidak memberikan kesempatan kepada siswa untuk menunjukkan kemampuan dan pengetahuan mereka. Harto"1 menyatakan bahwa kurang efektifnya pembelajaran agama disebabkan oleh dominasi model verbalistik dan normatif-doktriner yang dilakukan oleh seorang pengajar.

8 Rusman, Kurniawan, dan Riyana, Pembelajaran Berbasis Teknologi Informasi dan Komunikasi Mengembangkan Profesionalitas Guru, 74.

9 Rusman, Belajar dan Pembelajaran Berbasis Komputer (Bandung: Alfabeta, 2012), h. 16.

10 Mohammad Yazdi, "E-Learning Sebagai Media Pembelajaran Interaktif Berbasis Teknologi Informasi," Jurnal Ilmiah Foristek 2, no. 1 (2012), h. 146.

${ }^{11}$ Kasinyo Harto, "Developing Character Internalization Model In Islamic Education Through Value Clarification Technique," Madania: Jurnal Kajian Keislaman 19, no. 2 (2015), h. 137. 
E-learning merupakan produk TIK yang begitu populer dikalangan pelaku pendidikan. Dalam model pembelajaran yang berbantuan internet ini seseorang dapat mendapatkan akses informasi yang tidak terbatas. Azra' ${ }^{12}$ menyatakan bahwa TIK telah mempercepat demokratisasi dan equity dalam pembelajaran. Tenaga pendidik harus melakukan perubahan atau penyesuaian terhadap kehadiran TIK dalam pendidikan apabila tidak ingin peran mereka hilang. Karena kehadiran TIK membantu siswa untuk mengakses sumber belajar secara mandiri. Survey yang dilakukan oleh Asosiasi Penyelenggara Jasa Internet Indonesia (APJII) pada oktober 2016 mencatat bahwa 51, $8 \%$ atau sekitar 132,7 juta dari total populasi penduduk Indonesia merupakan pengguna internet $^{13}$. Lebih jauh lagi, APJII juga mencatat $65 \%$ dari angka tersebut merupakan penduduk yang tinggal di Pulau Jawa ${ }^{14}$. Untuk profesi yang berhubungan dengan pendidikan dan pembelajaran utamanya para guru dan dosen hanya 7,4 juta orang saja yang menggunakan internet, kalah dibandingkan dengan 18 juta orang atau sekitar $89 \%$ mahasiswa menempati peringkat pertama pengguna internet berdasarkan profesi $i^{15}$. 11, 3 juta pelajar juga mengalahkan guru dan dosen dalam hal penggunaan internet ${ }^{16}$.

Data yang dirilis oleh APJII di atas menunjukkan hal yang senada dengan Azra, bahwa peran guru akan tergantikan oleh kehadiran internet dan kemajuan teknologi adalah benar adanya ${ }^{17}$. Guru, ustadz, dosen, atau siapapun juga yang bergelut di dalam dunia pendidikan Islam semestinya harus merubah pola pikir serta tradisi dalam melakukan proses belajar dan pembelajaran yang sesuai dengan perkembangan zaman apabila perannya tidak ingin digantikan oleh mesin pencari informasi di internet semacam google. Mereka akan mengakses segala hal yang

12 Azyumardi Azra, Pendidikan Islam: Tradisi dan Modernisasi di Tengah Tantangan Milenium III, ed. Idris Thaha (Jakarta: Kencana Prenada Media, 2012), h. 52.

${ }^{13}$ APJII, “APJII - Statistik Oktober 2016," 2016, h. 4.

${ }^{14}$ APJII, “APJII - Statistik Oktober 2016," 2016, h. 4.

15 Wekke dan Hamid, "Technology on Language Teaching..., " 585 .

${ }^{16}$ Wekke dan Hamid, "Technology on Language Teaching..., " 585 .

${ }^{17}$ Azra, Pendidikan Islam: Tradisi dan Modernisasi di Tengah Tantangan Milenium III, 52. berhubungan dengan materi atau pengetahuan yang belum pernah mereka dapatkan di ruang kelas. Ketika hal ini tidak diimbangi oleh pengajar untuk mengunggah materi-materi yang mereka ampu, maka siswa lebih cenderung mempercayai informasi yang mereka temukan di internet walaupun diragukan kebenarannya.

Seluruh elemen di lingkungan lembaga pendidikan Islam harus memulai untuk membuat sebuah terobosan baru dalam hal proses pelaksanaan belajar dan pembelajaran. Selain materi di kelas, selayaknya mereka mengembangkan materi-materi tambahan yang diunggah dalam milis, blog ataupun website lembaga. Pengajar di era kemajuan teknologi ini harus mampu menjadi seorang penyedia informasi dan pusat deseminasi materi pembelajaran ${ }^{18}$. Dapat dikatakan bahwa guru harus merubah paradigma mereka tentang belajar dan pembelajaran dari cara-cara tradisional menuju budaya digital. Siswa akan mendapatkan materi yang sesuai dengan standar dan kurikulum yang ditetapkan oleh pemerintah. Kehawatiran tentang akses informasi dan pengetahuan yang tidak sesuai dengan ajaran-ajaran di lembaga pendidikan Islam tidak akan pernah terjadi.

\section{Lembaga Pendidikan Islam dan Open Learning}

Terdapat tiga institusi utama Pendidikan Islam di Indonesia diantaranya adalah (1) pengajian Quran; (2) belajar di pondok pesantren; dan (3) sekolah di madrasah ${ }^{19}$. Diantara ketiganya hanya madrasah yang mengadopsi model pendidikan modern seperti tingkatan kelas, buku teks, dan instruktur yang digaji untuk menyajikan pembelajaran keagamaan yang dipadukan dengan pelajaran umum ${ }^{20}$. Apabila kita menilik ketiga institusi pendidikan Islam di atas, hanya madrasah yang begitu dekat dengan teknologi. Madrasah sudah terbuka dengan internet,

\footnotetext{
${ }^{18}$ Richardus Eko Indrajit, E- Learning dan Sistem Informasi Pendidikan: Modul Pembelajaran Berbasis Standar Kompetensi dan Kualifikasi Kerja, 2 ed, (Yogyakarta: Preinexus, 2016), h. 129.

19 Robert W Hefner, "Islamic School, Social Movements, And Democracy in Indonesia," in Making Modern Muslims: The Politics of Islamic Education in Southeast Asia, ed. Robert W Hefner, (Honolulu: University of Hawai'i Press, 2009), h. 59.

${ }^{20}$ Robert W Hefner, "Islamic School, Social Movements ...,
} 
ataupun penggunaan gawai dalam proses belajar dan pembelajaran.

Ketika penggunaan TIK dapat dioptimalkan akan berdampak positif dalam dunia pendidikan. Ada banyak manfaat yang disumbangkan oleh produk-produk TIK seperti dalam penelitian yang dilakukan oleh Hismanoglu ${ }^{21}$ yang menyebutkan bahwa penggunaan TIK dalam pembelajaran dapat membantu siswa untuk belajar banyak hal. Pengalaman dalam proses pembelajaran berbantuan TIK dapat menambah khasanah dan wawasan baru bagi siswa. Kemudahan dan fleksibilitas yang ditawarkan oleh TIK akan membantu untuk menyelesaikan sebuah persoalan. $\mathrm{Hal}$ ini senada dengan Ola ${ }^{22}$ yang menyebutkan bahwa penggunaan TIK bagi pengajar dapat memberikan kemudahan dalam penyelesaian sebuah tugas pembelajaran. Motivasi dan personal interest siswa dipastikan meningkat ketika guru mengintegrasikan TIK dalam proses pembelajaran, karena siswa tidak hanya belajar di dalam kelas ${ }^{23}$. Suhirman ${ }^{24}$ menegaskan bahwa teknologi multimedia yang digunakan dalam proses pembelajaran dapat menyampaikan pengetahuan, keterampilan, dan sikap serta merangsang pikiran, perasaan, perhatian serta kemauan, sehingga proses pembelajaran akan lebih bermakna, mempunyai tujuan terkendali dan menyenangkan. Penggunaan teknologi dalam pembelajaran tidak hanya meningkatkan kualitas peserta didik di dalam lingkungan lembaga pendidikan Islam, tetapi juga dapat diakses dan dinikmati oleh semua orang diluar lembaga pendidikan Islam.

Tantangan kemajuan zaman dan globalisasi membuat semua elemen lembaga pendidikan Islam (termasuk di dalamnya guru, staff, kepala sekolah, komite dan orang tua) harus menyatukan

21 Murat Hismanoglu, “Prospective EFL Teachers' Perceptions of ICT Integration: A Study of Distance Higher Education in Turkey," Educational Technology \& Society 15, no. 1 (2012), h. 190.

$22 \mathrm{~J}$ Ola, "Assumptions about participating in teacher education through the use of ICT," Campus Wide Information Systems 22, no. 3 (2005), h. 160.

${ }^{23}$ Shelley S.C Young dan HsinHo Ku, "A Study of Uses of ICT in Primary Education through Four Winning School Cases in the Taiwan Schools Cyberfair," Educational Technology \& Society 11 , no. 3 (2008), h.58.

${ }^{24}$ Suhirman, "Pemanfaatan Teknologi Multimedia Dalam Pembelajaran Pendidikan Agama Islam," Madania: Jurnal Kajian Keislaman 19, no. 2 (2015), h. 223. pemikiran dan langkah untuk menghadapi tantangan kemajuan teknologi informasi dan komunikasi. Hal ini harus dilakukan untuk menemukan metode dan formula terbaik agar mencapai tujuan pembelajaran. Semua elemen harus lebih peka dan mampu menyesuaikan diri dengan kemajuan teknologi agar peran lembaga pendidikan Islam tidak tergerus dan hilang, karena telah terganti oleh produk-produk TIK yang memberikan kemudahan mendapatkan informasi secara mandiri kepada semua orang. Proses pembelajaran yang searah dan monoton harus dipangkas habis dan digantikan dengan proses pembelajaran yang lebih terpusat pada siswa. Pembelajaran ilmu agama memang berbeda dengan pembelajaran yang lain, siswa diharapkan tidak hanya mampu menjelaskan sebuah teori tetapi dapat melaksanakan pengetahuan keagamaan yang telah mereka pelajari dan berlaku secara positif sesuai dengan ajaran Islam dalam keseharian mereka.

Kaur, Shri dan Mital ${ }^{25}$ tentang penggunaan media sosial sebagai produk modernitas dalam penelitiannya menyatakan bahwa media sosial menyediakan platform yang lebih fleksibel, efektif dan menyenangkan untuk proses pembelajaran. Apabila model pembelajaran berbasis media sosial ini dapat diterapkan di semua lembaga pendidikan Islam, maka setiap orang akan mendapatkan akses untuk belajar ilmu-ilmu agama secara langsung, tanpa harus masuk ke dalam lembaga-lembaga Islam semacam pesantren. Karena sifat media sosial yang terbuka dan dapat menghubungkan jutaan orang, maka konsep open learning akan dirasakan oleh semua orang. Manfaat yang didapat tentu saja akan sangat besar, karena penyebaran ilmuilmu Agama yang murni dapat dinikmati oleh semua orang. Lebih lanjut Butcher dan WilsonStrydom ${ }^{26}$ menjelaskan tentang pembelajaran jarak jauh (Distance Education) yang menyediakan seperangkat metode dan strategi pembelajaran

${ }^{25}$ Irameet Kaur, Charu Shri, dan K. M. Mital, "A Flexible Approach Towards Effective Teaching: Use of Social Media by Teachers," Global Journal of Flexible Systems Management 16, no. 4 (2015), h. 401.

${ }^{26}$ Neil Butcher dan Merridy Wilson-Strydom, "Technology and Open Learning: The Potential of Open Education Resources for K-12 Education," in International Handbook of Information Technology in Primary and Secondary Education (Boston, MA: Springer US, 2008), h. 726. 
untuk mengatasi kendala ruang dan waktu antara pengajar dan peserta didik. Hal inilah yang akan menciptakan kemungkinan terjadinya open school dan open learning, yaitu sebuah institusi yang menyediakan pembelajaran dan program yang terbentuk karena adanya penggunaan metode pendidikan jarak jauh" ${ }^{27}$.

Berbicara tentang open learning, tidak akan pernah bisa lepas dari campur tangan teknologi di dalamnya. Teknologi mempunyai peranan dalam mengakselerasi skenario pembelajaran yang lebih bersifat independen, mandiri, dan panduan belajar yang menarik. ${ }^{28}$ Ketika kemerdekaan untuk mendapatkan ilmu dan belajar dikedepankan, maka konsep open learning akan dapat dirasakan untuk semua orang. Karena setiap orang berhak untuk mendapatkan informasi, ilmu pengetahuan dan pembelajaran. Caliskan menjelaskan bahwa open learning adalah sebuah situasi dimana peserta didik dapat memilih banyaknya pilihan metode pembelajaran, waktu, tempat, cara akses, dan segala faktor yang berhubungan dengan proses belajar secara bebas. ${ }^{29}$ Proses pembelajaran dan persebaran ilmu seharusnya tidak hanya terbatas pada ruang kelas ataupun lingkungan pendidikan tertentu saja, tetapi pembelajaran dapat dilakukan dimanapun, kapanpun dan dengan cara apapun. Hal-hal yang berkaitan dengan pembelajaran dapat dilakukan secara bebas sesuai dengan kehendak siapapun juga. Ketika semangat pembelajaran terbuka sudah didengungkan, tentunya keterbatasan ruang, waktu dan kesempatan akan dapat dihapuskan secara keseluruhan.

\section{Penggunaan Teknologi Informasi Di Lingkungan Lembaga Pendidikan Islam di Kudus}

Lembaga pendidikan Islam di Kabupaten Kudus menjadi salah satu penggerak utama persebaran ilmu-ilmu Islam. Menurut data yang dirilis oleh Badan Perencanaan Pembangunan Daerah (Bappeda) Kabupaten Kudus Provinsi Jawa Tengah Indonesia

${ }^{27}$ Neil Butcher dan Merridy Wilson-Strydom, "Technology and Open Learning: The Potential of Open ..., h. 727

28 Ulf-Daniel Ehlers, Open Learning Cultures (Berlin, Heidelberg: Springer Berlin Heidelberg, 2013), h. 1.

${ }_{29}$ Hasan Caliskan, "Open Learning," in Encyclopedia of the Sciences of Learning, ed. Norbert M. Seel (Boston, MA: Springer US, 2012), h. 2516. untuk jumlah pesantren, MI, MTS, dan MA pada tahun 2016 adalah sebagai berikut:

Tabel 1:

Jumlah lembaga pendidikan Islam di Kabupaten Kudus, Jawa Tengah Indonesia.

\begin{tabular}{lc}
\hline \multicolumn{1}{c}{ Lembaga } & Jumlah (Unit) \\
\hline Pesantren & 152 \\
Madrasah Ibtidaiyah (MI) & 141 \\
Madrasah Tsanawiyah (MTS) & 64 \\
Madrasah Aliyah (MA) & 35 \\
Sekolah Tinggi Agama Islam Negeri (STAIN) & 1 \\
$\quad$ Total & 393 \\
\hline Sumber: Website Bappeda Kabupaten Kudus tahun $2016^{30}$
\end{tabular}

Sumber: Website Bappeda Kabupaten Kudus tahun $2016{ }^{30}$

Dalam artikel ini observasi dan penyebaran questionnaire dilakukan pada 76 pesantren di Kabupaten Kudus. Kenapa observasi dan wawancara hanya dilakukan di pesantren; Pertama, karena banyak tenaga-tenaga pengajar di pesantren yang juga menjadi pengajar di lembagalembaga semacam MI, MTs, ataupun MA. Kedua, pesantren juga menjadi induk dan sumber ilmu bagi lembaga pendidikan Islam formal, karena pesantren menghasilkan santriwan-santriwati yang berpotensi menjadi pengajar bagi institusi pendidikan Islam yang lainnya. Ketiga, pesantren selalu identik dengan tradisionalitas dan tidak semuanya mengadopsi konsep modern. Keempat, pesantren menjadi tempat dimana ilmu-ilmu agama yang otentik diajarkan. Kelima, pesantren memiliki kemerdekaan dalam hal tata kelola, aturan dan sistem pembelajaran yang tidak bisa dipengaruhi oleh siapapun. Hal inilah yang menjadi tantangan di era keterbukaan informasi saat ini, bagaimana peran pesantren dalam mendukung keterbukaan informasi menjadi kajian yang sangat penting untuk perkembangan lembaga pendidikan Islam serta untuk penyebaran ajaran agama secara global.

Hasil observasi dan sebaran questionnaire menunjukkan bahwa beberapa pesantren sudah mulai membuka diri untuk menggunakan produkproduk teknologi informasi dan komunikasi walaupun dengan jumlah yang minim. Ada sekitar 21, 1\% atau sekitar 16 pondok pesantren

${ }^{30}$ Bappeda Kabupaten Kudus, "Detail Daerah - Sosial Budaya," Website Bappeda Kabupaten Kudus, last modified 2016, http://bappeda.kuduskab.go.id/detaildaerah.php?id=3. diakses tanggal 16 April 2017. 
yang memiliki jaringan internet. Sisanya 78 , $9 \%$ atau sekitar 60 pesantren tidak memiliki jaringan internet (Gambar 1). Pesantren yang tidak memiliki jaringan internet merasa belum membutuhkan bantuan perangkat-perangkat tersebut, karena mereka masih mempertahankan model-model pembelajaran tradisional yang masih sangat relevan dengan kondisi saat ini. Beberapa pesantren juga memberikan kesempatan kepada santri untuk mengakses jaringan internet melalui gawai yang mereka miliki. Ada $46,1 \%$ atau sekitar 35 pondok pesantren yang mengijinkan santrinya untuk mengakses internet, sedangkan 53,9\% atau sekitar 41 pesantren tidak mengizinkan santrinya untuk mengakses internet.

Pondok pesantren yang mengizinkan santrinya mengakses internet karena santri mereka merupakan pelajar dan mahasiswa yang membutuhkan akses internet untuk mendapatkan datadata ataupun informasi yang berkaitan dengan tugas sekolah ataupun perkuliahan. Hal ini juga menjadi alasan kenapa beberapa pondok pesantren memasang jaringan internet di lingkunan mereka. Dari hasil questionnaire yang disebarkan diketahui bahwa beberapa pondok pesantren yang tidak mengizinkan santrinya mengakses jaringan internet karena fasilitas ini hanya digunakan untuk keperluan lembaga. Selain itu adanya anggapan dari pengelola pesantren bahwa ketika menerapkan pembelajaran berbasis daring maka hanya akan mengganggu proses penyampaian materi dan pembelajaran yang sudah berjalan sejak lama. Sebagai contoh di salah satu pondok tahfidz, mereka melarang penggunaan internet karena dikhawatirkan akan mengganggu proses menghafal para santri. Dengan pembelajaran berbasis daring akan memecah konsentrasi santri dalam menghafal.

\section{Apakah sudah terdapat jaringan internet?}

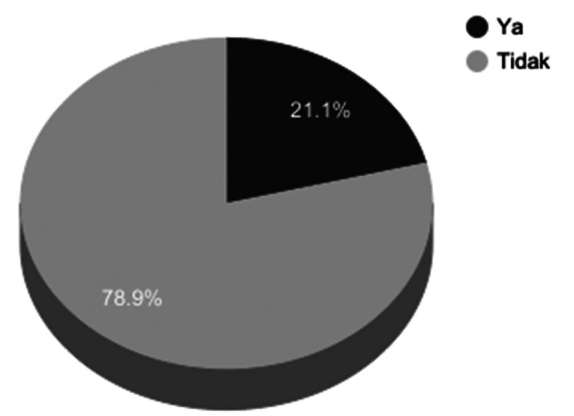

Gambar 1: Jumlah jaringan internet pada 76 pondok pesantren di Kabupaten Kudus.
Adanya fasilitas internet di beberapa pondok pesantren, bukan berarti semuanya memiliki halaman website. Dari 76 pesantren hanya 2 pesantren saja yang mempunyai website. 74 pesantren lainnya, tidak memiliki website (Gambar 2).

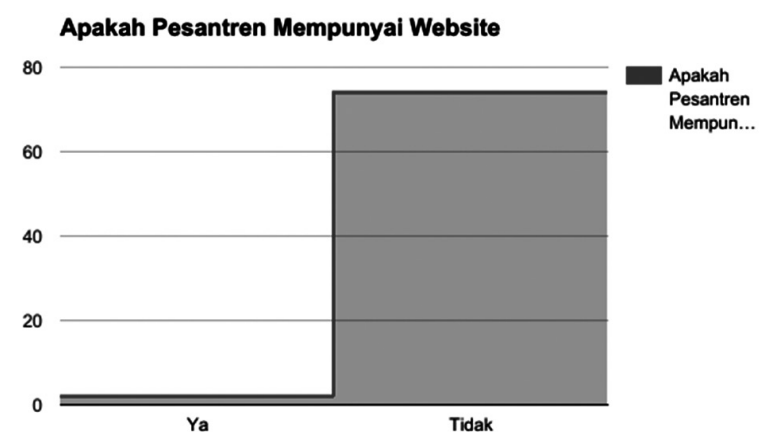

Gambar 2: Perbandingan pondok pesantren yang memiliki website.

Website hanya digunakan untuk menampilkan profil dari pesantren bukan untuk kepentingan pembelajaran ataupun untuk mengunggah ilmuilmu keislaman. Sejatinya, apabila fasilitas internet dapat dimanfaatkan oleh pengurus pesantren untuk mengunggah materi-materi pembelajaran di pesantren maka peluang untuk menyebarluaskan ilmu agama semakin terbuka. Kesempatan khalayak luas untuk belajar ilmu agama tanpa harus menetap di pondok pesantren dapat menjadi kelebihan dari model pembelajaran open learning. Tidak adanya pengelola khusus menjadikan website di lingkungan pesantren terbengkalai. Dibutuhkan seseorang yang mampu menguasai manajemen pengelolaan website serta maintenance agar keberlangsungan situs-situs website pesantren tetap terjaga.

Berbicara tentang open learning, e-learning ataupun pembelajaran berbantuan teknologi lainnya $23,7 \%$ atau sekitar 18 pengelola pesantren mengetahui perihal e-learning. $76,3 \%$ atau sekitar 58 pengelola pesantren tidak mengenal open learning maupun e-learning (Gambar 3).

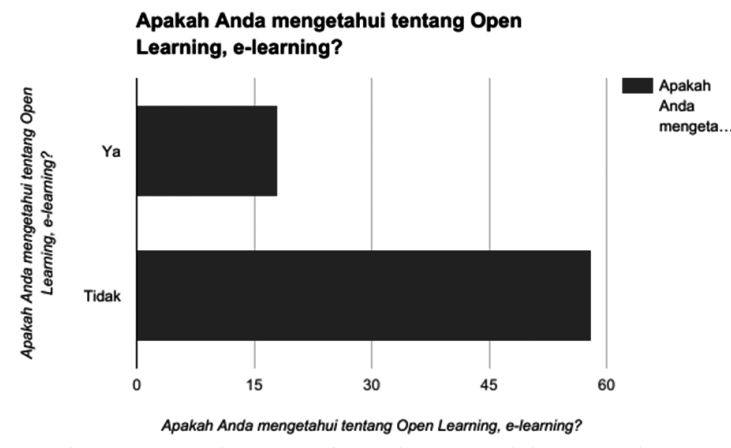

Gambar 3: Open learning dan e-learning dalam pandangan pengelola pesantren. 
Pengelola pesantren tidak terlalu menutup diri mengenai open learning, walaupun jumlahnya lebih kecil jika dibandingkan dengan pesantren yang tidak ingin menerapkannya. Ada $23,7 \%$ atau sekitar 18 pengelola pesantren mempunyai keinginan untuk mencoba menerapkan open learning dalam lingkungan mereka. 76, 3\% atau sekitar 58 orang pengelola pesantren yang mengatakan tidak akan pernah mencoba hal-hal di luar tradisi pesantren yang selama ini dijalankan (Gambar 4).

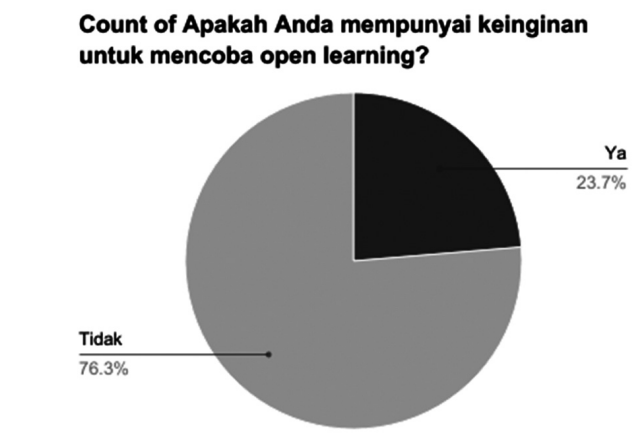

Gambar 4: Persepsi pengelola untuk menerapkan open learning

Sebagaian besar pengelola pesantren di Kabupaten Kudus menyatakan bahwa penerapan open learning dalam pesantren mereka masih terkendala minimnya fasilitas pendukung seperti internet dan laboratorium komputer.

\section{Persepsi Pengelola dan Masa depan Pembelajaran Terbuka di Lembaga Pendidikan Islam}

Seorang berkebangsaan Jerman bernama Leibniz ${ }^{31}$ menyatakan bahwa persepsi merupakan sebuah tindakan yang dilakukan oleh seseorang ketika menerima sebuah data dari luar. Sedangkan Walgito $^{32}$ mendefinisikan bahwa persepsi merupakan sebuah proses diterimanya stimulus oleh individu melalui alat indera atau biasa disebut proses sensoris dan diteruskan ke syaraf menuju otak untuk selanjutnya merupakan persepsi. Dari beberapa uraian di atas dapat dikatakan bahwa persepsi pengelola lembaga pendidikan Islam terhadap pembelajaran terbuka adalah penerimaan

${ }^{31}$ Stanford University. dan Center for the Study of Language and Information (U.S.), Stanford encyclopedia of philosophy, (Stanford University, 1997).

${ }^{32}$ Bimo Walgito, Psikologi sosial (suatu pengantar), (Andi Offset, 1991), h. 55 . informasi terhadap pembelajaran terbuka yang diterjemahkan dalam tindakan, gagasan ataupun tanggapan terhadap hal tersebut.

Adapun persepsi pengelola pesantren di Kabupaten Kudus untuk menggagas open learning dapat dikategorikan dalam beberapa pendapat. Pertama, pengelola yang berkeinginan untuk mengembangkan pembelajaran terbuka. Pembelajaran terbuka sangat baik dan dapat meningkatkan minat santri. Karena para santri dapat menambah pengetahuan mereka diluar materimateri pesantren, sehingga kemampuan mereka akan berimbang antara pengetahuan umum dan pengetahuan agama. Internet dianggap sebagai produk kemajuan dan dapat menunjang proses pembelajaran santri di pesantren maupun di tempat belajar formal lainnya. Adanya pengembangan pembelajaran berbasis terbuka dengan bantuan internet menepis stigma negatif masyarakat bahwa santri selalu "gaptek" (gagap teknologi), ketinggalan jaman dan tidak modern. Ada satu pondok pesantren yang sudah memanfaatkan teknologi internet untuk pembelajaran jarak jauh. Pondok Pesantren Al-Irsyad di Desa Ngembalrejo, Kecamatan Bae Kabupaten Kudus dalam pengajaran atau kajian menggunakan fasilitas teleconference dengan skype. Hal ini merupakan inovasi yang diberlakukan oleh pengurus pesantren karena salah satu ustadz mereka berada di luar negeri. Selain itu, di pesantren ini juga digunakan media video yang disesuaikan dengan tema kajian. Santri juga diberikan kebebasan untuk mempergunakan laptop dan fasilitas internet, karena mayoritas santri adalah mahasiswa yang mempunyai banyak tugas kuliah dan membutuhkan referensi yang banyak.

Kedua, bagi sebagian besar pesantren yang masih tetap mempertahankan sistem pembelajaran dan penyebaran informasi secara tradisional berpendapat bahwa minimnya informasi dan pengetahuan yang berkaitan dengan pembelajaran berbasis daring ataupun open learning menjadi kendala terbesar dalam pengembangan pembelajaran terbuka. Beberapa pengelola menganggap bahwa pembelajran terbuka dengan bantuan daring hanya untuk sekolah yang modern atau untuk sekolah formal saja. Pengelola menganggap pemberian materi selama 24 jam di 
lingkungan pondok sudah lebih dari cukup untuk para santri. Tetapi hal ini apabila dikaitkan dengan tujuan pembelajaran terbuka sangat bertentangan, karena hanya para santri yang mondok saja yang mendapatkan materi-materi dari kiai, ustadz atau pembina pesantren. Masyarakat umum yang tidak mondok tidak akan pernah mengetahui ilmuilmu yang diajarkan di pesantren. Oleh karena itu kampanye-kampanye dan hal-hal yang mengedukasi pengelola pesantren tentang open learning dan pembelajaran berbasis daring perlu diberikan. Kendala lain yang menjadikan alasan pengelola tidak mengembangkan open learning adalah hanya sedikit santri mempunyai pegawai atau perangkat-perangkat yang dapat digunakan untuk mengakses materi-materi secara online. Selain itu pihak pesantren juga terkendala dengan sarana dan prasarana yang terbatas.

Ketiga, semangat untuk mempertahankan tradisionalitas dan kekhasan pesantren masih sangat kuat. Banyak pengelola pesantren yang menganggap bahwa pembelajaran terbuka berbasis daring memungkinkan bagi santri untuk mengikuti pembelajaran tanpa harus bertemu dengan pengasuh pondok pesantren ataupun ustadz dan kiai. Pengelola pesantren menganggap bahwa hal ini akan mengurangi keberkahan dalam proses belajar dan pembelajaran. Selain itu tipikal pembelajaran berbasis daring adalah pembelajaran yang independen sehingga hal ini dianggap tidak maksimal karena santri tidak secara langsung bertemu dengan pengajar. Beberapa alasan di atas menjadi faktor utama bagi beberapa pengelola pesantren untuk tetap mempertahankan tradisi dalam proses belajar dan pembelajaran di lingkungan mereka.

Pengembangan open learning pada pesantren dan lembaga pendidikan Islam di kabupaten Kudus di masa depan masih sangatlah besar, walaupun mayoritas pengelola pesantren tidak pernah mengenal open learning, e-learning ataupun pembelajaran berbantuan internet sebelumnya. Hal ini dapat dilihat dari persepsi beberapa pengelola pesantren yang ingin mencoba mengembangkan proses belajar dan pembelajaran dengan bantuan internet dan sosial media untuk menggagas open learning. Pengelola pesantren yang enggan untuk mencoba pembelajaran terbuka memang mempunyai alasan tersendiri, tetapi apabila menginginkan sebuah kemerdekaan dalam mengakses informasi dan ilmu pengetahuan tanpa batasan seharusnya konsep open learning juga harus dilakukan di lembaga-lembaga pendidikan Islam seperti pesantren untuk mewujudkan keterbukaan dan persebaran ilmu-ilmu agama yang murni kepada khalayak luas.

\section{Penutup}

Lembaga pendidikan Islam terutama pesantren merupakan sebuah lembaga yang unik, independen dan tidak pernah terintervensi oleh apapun. Tradisi pesantren yang kental menjadikan pengelola pondok pesantren di Kabupaten Kudus Jawa Tengah mayoritas lebih memilih untuk mempertahankan model pembelajaran secara klasikal alih-alih untuk mencoba mengembangkan model pembelajaran terbuka (open learning course). Sifat pembelajaran terbuka yang independen, tidak terbatas ruang dan waktu dianggap kurang efektif dan menghilangkan keberkahan karena santri dan pengajar tidak bertemu secara langsung. Bukan berarti peluang untuk menerapkan open learning course pada lembaga-lembaga pendidikan Islam di Kabupaten Kudus tertutup, karena ada sebagian pesantren yang mulai membuka diri terhadap teknologi dan pembelajaran berbasis daring. Beberapa pesantren yang mempunyai website dan fasilitas jaringan internet juga belum memanfaatkannya secara maksimal untuk kebutuhan pembelajaran dan persebaran ilmu-ilmu agama. Peningkatan sarana dan prasarana di lingkungan lembaga pendidikan Islam sangat dibutuhkan untuk menunjang kelancaran pembelajaran terbuka berbasis daring. Adanya pendekatan dan sosialisasi tentang pembelajaran terbuka serta penerapan teknologi kepada pengelola lembaga pendidikan Islam akan membuka wawasan dan wacana yang baru tentang hal tersebut, sehingga cita-cita untuk menyebarkan ilmu-ilmu agama yang otentik akan terwujud di masa yang akan datang.

\section{Pustaka Acuan}

APJII, “APJII - Statistik Oktober 2016," 2016.

Azra, Azyumardi, Pendidikan Islam: Tradisi dan Modernisasi di Tengah Tantangan Milenium 
III. Diedit oleh Idris Thaha. Jakarta: Kencana Prenada Media, 2012.

Bappeda Kabupaten Kudus, "Detail Daerah - Sosial Budaya." Website Bappeda Kabupaten Kudus. Last modified 2016. Diakses April 16, 2017. http://bappeda.kuduskab.go.id/detaildaerah. php?id=3.

Butcher, Neil, dan Merridy Wilson-Strydom, "Technology and Open Learning: The Potential of Open Education Resources for K-12 Education." In International Handbook of Information Technology in Primary and Secondary Education, 725-745. Boston, MA: Springer US, 2008.

Caliskan, Hasan, "Open Learning." In Encyclopedia of the Sciences of Learning, diedit oleh Norbert M. Seel, 2516-2518. Boston, MA: Springer US, 2012.

Chisalita, Oana, dan Carmen Cretu, "Opinions and Attitudes of Students Teachers' Toward ICT Use in Education." In The 8 th International Scientific Conference eLearning and software for Education, 548-553, 2012.

Ehlers, Ulf-Daniel, Open Learning Cultures. Berlin, Heidelberg: Springer Berlin Heidelberg, 2013. Harto, Kasinyo, “Developing Character Internalization Model In Islamic Education Through Value Clarification Technique." Madania: Jurnal Kajian Keislaman 19, no. 2 (2015): 137-146.

Hefner, Robert W, "Islamic School, Social Movements, And Democracy in Indonesia." In Making Modern Muslims: The Politics of Islamic Education in Southeast Asia, diedit oleh Robert W Hefner, 55-105. Honolulu: University of Hawai'i Press, 2009.

Hismanoglu, Murat, “Prospective EFL Teachers' Perceptions of ICT Integration: A Study of Distance Higher Education in Turkey." Educational Technology \& Society 15, no. 1, 2012. Husain, Chaidar, "Pemanfaatan Teknologi Informasi dan Komunikasi dalam Pembelajaran di SMA Muhammadiyah Tarakan." Jurnal Kebijakan dan Pengembangan Pendidikan 2, no. 2, 2014. Indrajit, Richardus Eko, E- Learning dan Sistem Informasi Pendidikan: Modul Pembelajaran Berbasis Standar Kompetensi dan Kualifikasi Kerja. 2 ed. Yogyakarta: Preinexus, 2016.
Kaur, Irameet, Charu Shri, dan K. M. Mital, "A Flexible Approach Towards Effective Teaching: Use of Social Media by Teachers." Global Journal of Flexible Systems Management 16, no. 4, 2015.

Ola, J. "Assumptions about participating in teacher education through the use of ICT." Campus Wide Information Systems 22, no. 3, 2005.

Rosyid, Moh, “Diniyah Muawanatul Muslimin Sejak Era Pra-Kolonial Dengan Diberlakukannya Perda Kabupaten Kudus Tentang Madin Takmiliyah." Elementary 3, no. 1, 2015.

Rusman, Belajar dan Pembelajaran Berbasis Komputer. Bandung: Alfabeta, 2012.

Rusman, Deni Kurniawan, dan Cepi Riyana, Pembelajaran Berbasis Teknologi Informasi dan Komunikasi Mengembangkan Profesionalitas Guru. PT. Raja Grafindo Persada. Depok: PT Raja Grafindo Persada, 2012.

Stanford University., dan Center for the Study of Language and Information (U.S.). Stanford encyclopedia of philosophy. Stanford University, 1997.

Suhirman, "Pemanfaatan Teknologi Multimedia Dalam Pembelajaran Pendidikan Agama Islam." Madania: Jurnal Kajian Keislaman 19, no. 2, 2015..

Walgito, Bimo, Psikologi sosial (suatu pengantar). Andi Offset, 1991.

Wekke, Ismail Suardi, dan Sanusi Hamid, "Technology on Language Teaching and Learning: A Research on Indonesian Pesantren." Procedia - Social and Behavioral Sciences 83, 2013.

Yazdi, Mohammad, "E-Learning Sebagai Media Pembelajaran Interaktif Berbasis Teknologi Informasi." Jurnal Ilmiah Foristek 2, no. 1, 2012.

Young, Shelley S.C, dan HsinHo Ku, "A Study of Uses of ICT in Primary Education through Four Winning School Cases in the Taiwan Schools Cyberfair." Educational Technology \& Society 11, no. 3, 2008. 